\title{
Sobre o eugenismo e sua justificação maquiaveliana em Nietzsche*
}

\author{
Emmanuel Salanskis ${ }^{* *}$
}

\begin{abstract}
Resumo: A tese central deste artigo é que Nietzsche desenvolveu um projeto eugenista, justificando-o por considerações maquiavelianas. Por eugenismo, entendemos uma ideologia política preconizando o controle da reprodução a serviço de uma imagem normativa do homem. A primeira parte (I) procura estabelecer a pertinência histórica dessa definição. Em seguida, argumentamos em favor da existência de um eugenismo nietzschiano (II). Essa interpretação é fundamentada por textos publicados e póstumos, assim como pelas fontes eugenistas de Nietzsche, das quais priorizamos os autores contemporâneos, sem omitir Platão. Por fim, a terceira parte (III) coloca em evidência um certo maquiavelismo do eugenismo nietzschiano, segundo o qual seria preciso reprimir a compaixão em nome de um fim superior.
\end{abstract}

Palavras-chave: eugenismo - biopolítica - Galton - maquiavelismo

O desenvolvimento recente dos estudos nietzschianos trouxe uma nova luz à questão controversa do eugenismo nietzschiano. Logo após a Segunda Guerra Mundial, essa questão havia recebido uma resposta negativa de comentadores que combatiam as interpretações nazistas para reabilitar filosoficamente Nietzsche ${ }^{1}$. Um tal procedimento correspondia então a uma necessidade histórica. Mas ele tinha de fazer passar em silêncio certos textos e conceitos,

\footnotetext{
* Tradução de Eder Corbanezi.

** Pós-doutorando USP/FAPESP, São Paulo, Brasil. E-mail: emmanuel.salanskis@noos.fr.

1. Cf. KAUFMANN, W. Nietzsche. Philosopher, Psychologist, Antichrist. Princeton: Princeton University Press, 1974 (1950 para a primeira edição), p. 284-306.
} 
Salanskis, E.

como testemunham as três breves páginas que Walter Kaufmann consagra à noção de criação (Züchtung) em seu livro de $1950^{2}$. O momento do pós-guerra constituiu, parece, uma ruptura na história das recepções de Nietzsche: ruptura não somente com as apropriações do Terceiro Reich, mas com leituras anteriores, inclusive acadêmicas, que sublinhavam ao contrário a proximidade do filósofo com o eugenismo pós-darwiniano. Em sua tese de doutorado publicada em 1911, Claire Richter escrevia assim sem ambiguidade: "Nietzsche aconselha à humanidade a seleção consciente" . Porém, esse aspecto do comentário de Richter é novamente defendido por um número significativo de intérpretes desde o fim dos anos $1990^{4}$. Mesmo se esse ponto não é consensual e não resolve todas as dificuldades, ele nos parece levar em conta textos que, de fato, os comentadores não liam mais, ou reduziam de modo pouco convincente a um estatuto puramente metafórico. A tese central deste artigo é que Nietzsche efetivamente desenvolveu uma forma de eugenismo.

Argumentando nesse sentido, não teremos por objetivo infligir ao filósofo uma pura e simples nota de infâmia. Não desejamos

2 Ibid., p. 304-306. Segundo Kaufmann, a criação seria apenas uma ideia embrionária e pouco documentada no corpus nietzschiano.

3 Cf. RICHTER, C. Nietzsche et les théories biologiques contemporaines. Paris: Mercure de France, 1911, p. 143. Entre as leituras extra-acadêmicas que associaram precocemente Nietzsche ao eugenismo, pode-se citar a de Alexander Tille, cujo objetivo reivindicado era de "aplicar a todos os domínios da vida moral assim como à existência popular os dois princípios da seleção social e da exclusão social” (cf. TILLE, A. Von Darwin bis Nietzsche. Ein Buch Entwicklungsethik. Leipzig: C. G. Naumann, 1895, p. vii-viii, trad. francesa E. Salanskis e trad. para o português E. Corbanezi, e ASCHHEIM, S. The Nietzsche Legacy in Germany 1890-1990. University of California Press, 1992, p. 123-125). Para outras recepções eugenistas na Inglaterra, ver STONE, D. Breeding Superman: Nietzsche, Race and Eugenics in Edwardian and Interwar Britain, Liverpool University Press, 2002.

4 Cf. MOORE, G. Nietzsche, Biology and Metaphor. Cambridge University Press, 2002, p. 128138; GAYON, J. Nietzsche and Darwin. In: MAIENSCHEIN, J./RUSE, M. (ed.) Biology and the Foundation of Ethics. Cambridge University Press, p. 154-197, 1999, em particular p. 173-185; HOYER, T. Nietzsche und die Pädagogik: Werk, Biografie und Rezeption. Würzburg: Königshausen / Neumann, 2002, p. 634-642; SALANSKIS, E. La dimension eugéniste de la "grande politique" de Nietzsche. In: Nietzsche, penseur de la politique? Nietzsche, penseur du social ? In: CAMPIONI, G. / DENAT, C. / PIAZZESI, Ch. / WOTLING, P. (Org.) Nietzsche, penseur de la politique? Nietzsche, penseur du social? Pisa: ETS 2013, p. 163-178 (no prelo), p. 163-178. 
isentar Nietzsche de sua responsabilidade diante da história. Mas as reticências dos especialistas sobre esse assunto parecem às vezes ligadas a ideias admitidas sobre o eugenismo: sua assimilação imediata ao nazismo, a ignorância ou a minimização de suas fontes biológicas, a crença errônea de que ele seria por definição coercitivo, enfim, a ideia historicamente falsa de que ele emanaria unicamente de pensadores reacionários. Assim, examinaremos na primeira parte o problema definicional que o eugenismo coloca na segunda metade do século 19. Depois, em um segundo momento, analisaremos os argumentos que foram evocados para justificar ou contestar a palavra "eugenismo" no caso de Nietzsche. Partindo de nossas considerações definicionais, sustentaremos que os argumentos contra não fazem justiça à vontade nietzschiana, expressa em textos publicados e póstumos, de levar adiante uma biopolítica da hereditariedade. A esse propósito, nosso filósofo fala, ele próprio, em "grande política"5. Admitindo que ele inclua nessa expressão um controle da reprodução humana, nós nos interrogaremos em um terceiro momento sobre o tipo de justificação que ele propõe em favor de seu projeto. Evidenciaremos então um maquiavelismo deliberado, a partir de uma comparação entre o projeto de Tractatus politicus de 1887-1888 e o capítulo "Os 'melhoradores' da humanidade" do Crepúsculo dos ídolos. Isso nos conduzirá por fim a uma reflexão sobre os limites axiológicos de um pensamento maquiaveliano.

\section{O problema definicional à luz do contexto histórico}

Por razões ao mesmo tempo lógicas e históricas, o problema de uma definição adequada do eugenismo parece primordial. Por um lado, os lógicos sabem que sempre se pode excluir uma instância da

5 Cf. JGB/BM 208, KSA 5.140 e 251, KSA 5.195; EH/EH, Por que sou um destino 1 , KSA 6.366; e, sobretudo, Nachlass/FP 1888, 25[1], KSA 13.637. 
Salanskis, E.

extensão de um conceito, se se autoriza a modificação da definição correspondente. Por outro lado, as definições de tal objeto histórico não são igualmente admissíveis, na medida em que algumas delas excluem autores, obras ou legislações que efetivamente evocaram o termo definido. Desse ponto de vista, a definição aparece como um problema contextual: o que não é surpreendente a propósito de uma ideologia que marcou uma época ${ }^{6}$. Várias ideias errôneas ou contestáveis sobre a história do eugenismo devem, portanto, ser discutidas, antes que nós possamos delinear uma definição do termo aplicável a Nietzsche.

Gostaríamos primeiramente de sublinhar que a questão do eugenismo não se confunde com a do nazismo ${ }^{7}$. O termo eugenics foi forjado em 1883 pelo inglês Francis Galton, primo de Darwin e autor de uma obra importante sobre as faculdades hereditárias do homem ${ }^{8}$. De resto, sabe-se que o fisiologista austríaco Joseph Paneth ofereceu esse livro a Nietzsche em março de 1884 e que o filósofo provavelmente beneficiou de uma tradução in extenso ${ }^{9}$. No capítulo 4, Galton introduz o neologismo eugenics, definindo-o da seguinte maneira:

a ciência da melhoria das linhagens, que não se limita de modo algum a questões de cruzamento judicioso, mas que, particularmente no caso do homem, toma conhecimento de todas as influências que tendem, ainda que em um grau remoto, a dar às raças ou às estirpes sanguíneas

6 Sobre a época em que a palavra "eugenismo" foi expressa e positivamente reivindicada, isto é, durante os dois últimos decênios do século 19 e os quatro primeiros do século 20, cf. PAUL, D., Controlling Human Heredity : 1865 to the Present. New York: Humanity Books, 1998 (doravante Controlling Human Heredity...), Cap. 1: "What is Eugenics ? Why Does It Matter?", p. 1-21.

7 Cf. PICHOT, A. L'Eugénisme ou les généticiens saisis par la philanthropie. Paris: Hatier, 1995 (doravante L'Eugénisme..., p. 34-40.

8 Cf. GALTON, F. Inquiries into Human Faculty and its Development. London: Macmillan, 1883 (doravante Inquiries...).

9 Cf. FRANK KRUMMEL, R. Joseph Paneth über seine Begegnung mit Nietzsche in der Zarathustra-Zeit. In: Nietzsche-Studien. Berlim/Nova York, n.17, p. 478-495, 1988, em particular p. 489, e HAASE, M.-L. Friedrich Nietzsche liest Francis Galton. In: NietzscheStudien. Berlim/Nova York, n.18, p. 633-658, 1989. 
mais convenientes uma chance maior de prevalecer rapidamente sobre as menos convenientes ${ }^{10}$.

Essa caracterização exige uma primeira observação essencial. Ela é devida a um autor inglês que escreve no século 19, o que atesta, contrariamente a uma opinião corrente, que o eugenismo pós-darwiniano não nasceu na Alemanha no contexto do Terceiro Reich. Cinquenta anos antes da ascensão do nazismo ao poder, Galton apresentava um projeto técnico-científico visando a "suplantar as linhagens humanas ineficientes por estirpes melhores"11. Além disso, não se pode considerar que o Estado nazista tenha sido o primeiro a aplicar esse tipo de programa. Medidas eugenistas foram de fato legalizadas em várias democracias ocidentais antes de 1933, inclusive sob a forma de esterilizações forçadas, como foi o caso em vários estados americanos a partir de $1907^{12}$.

Uma segunda observação capital concerne à articulação entre teorias biológicas e um projeto técnico na definição de Galton. Para introduzir sua eugenia, Galton se apoia ao mesmo tempo em uma doutrina da hereditariedade e na teoria da evolução darwiniana. Desde 1865, ele se empenha para justificar uma seleção artificial aplicada ao homem pela hipótese de que as faculdades morais e intelectuais são em grande parte hereditárias ${ }^{13}$. Assim, ele publicou

10 Cf. GALTON, F. Id., p. 25.

11 Cf. GALTON, F. Id., p. 2.

12 Cf. PAUL, D., Controlling Human Heredity..., p. 82-87. Indiana foi o primeiro estado americano a dotar-se de medidas de esterilização coercitiva em 1907. Historiadores mostraram que os programas eugenistas americanos haviam sido evocados como modelos pelas autoridades nazistas. Estima-se que cerca de 50.000 indivíduos foram legalmente esterilizados nos Estados Unidos entre 1907 e 1949 (cf. GAYON, J. Le mot "eugénisme" est-il encore d'actualité? In: GAYON, J. / JACOBI, D(dir.) L'Éternel retour de l'eugénisme. Paris: PUF, 2006, p. 132-133.

13 Cf. GALTON, F. Hereditary Talent and Character. In: MacMillan's Magazine, London, vol. XII, p. 157-166 / p. 318-327, junho-agosto de 1865. Cita-se frequentemente uma frase emblemática do artigo: "Eu constato que o talento é, em um grau muito notável, transmitido por hereditariedade" (ibid., p. 157). Sobre a concepção de hereditariedade de Galton, ver igualmente: GALTON, F. Hereditary Genius: An Inquiry into its Laws and Consequences. 
numerosos trabalhos estatísticos e antropométricos que, conduzindo invariavelmente à mesma conclusão, contribuíram para promover a oposição moderna entre o inato e o adquirido ${ }^{14}$. Precisemos que, do ponto de vista da história das ciências, os métodos de investigação de Galton geralmente não eram satisfatórios. Eles repousavam principalmente no recurso a dicionários biográficos e a questionários orientados, o que excluía, de maneira insuficientemente crítica, a possibilidade de que uma transmissão cultural tenha produzido os efeitos imputados à hereditariedade biológica ${ }^{15}$. Mas não está aqui o ponto que nos ocupa. Sem o desenvolvimento contemporâneo de uma problemática da hereditariedade, o eugenismo teria sido privado de seu fundamento mais imediato. Em segundo lugar, Galton dá sentido a seu projeto no quadro científico fornecido pela teoria da evolução darwiniana. Ele deseja, com efeito, "promover os fins da evolução mais rapidamente e com menos sofrimento do que se os acontecimentos fossem deixados ao seu próprio curso" "16. É verdade que certos historiadores do darwinismo colocaram em dúvida esse vínculo reivindicado entre o eugenismo de Galton e a teoria da seleção natural. Um argumento frequentemente proposto é o da posição pessoal de Darwin, expressa em $A$ origem do homem $^{17}$. Em última análise, todavia, esse argumento deve ser nuançado. Antes de tudo, Darwin evoca razões morais para recusar o eugenismo: ele não contesta a existência de uma relação conceitual entre sua teoria e o

London: Macmillan, 1869. Lembremos que Nietzsche menciona essa outra obra em uma carta de 8 de dezembro de 1888 a August Strindberg.

14 Cf. LENAY, Ch. Francis Galton: inné et acquis chez les grands hommes de la Société Royale de Londres. In : Bulletins et Mémoires de la Société d'anthropologie de Paris. Tomo 6 , Fascículo 1-2, 1994, p. 135-150.

15 Ibid., p. 137.

16 Cf. GALTON, F. Inquiries..., p. 2. Na segunda parte, nós retornaremos ao argumento filantrópico que é apresentado aqui.

17 Cf. TORT, P. L'Effet Darwin: sélection naturelle et naissance de la civilisation. Paris: Seuil, 2008, p. 30, e DARWIN, Ch. A origem do homem e a seleção sexual. Curitiba: Hemus, 2002 (doravante $A$ origem do homem), p. 162. 
programa de Galton ${ }^{18}$. Não se pode, portanto, nem afirmar que o eugenismo é uma consequência lógica do darwinismo, nem negar que o primeiro tenha encontrado um fundamento teórico no segundo.

Detenhamo-nos por um instante nessa ancoragem biológica do eugenismo. É essencial no plano sociológico para compreender a rápida difusão dessa ideologia na segunda metade do século 19. Hoje, como observou André Pichot, muitos biólogos esqueceram esse aspecto da história de sua disciplina ${ }^{19}$. A atitude deles pôde levar ao erro os historiadores das ideias que abordavam o eugenismo sem competência específica em história da biologia. De fato, esses últimos eram tentados a superestimar a importância de ideólogos mais isolados, tais como o conde Arthur de Gobineau. Nós subscrevemos, todavia, o julgamento de André Pichot, segundo o qual "a biologia, e especialmente a genética da primeira metade do século [20], estava profundamente impregnada de uma preocupação eugenista"20. Diane Paul resumiu essa situação em uma fórmula muito clara: "Nos anos 1910 e 1920, a eugenia era simplesmente considerada como genética humana aplicada"21.

As considerações precedentes nos permitem discutir uma primeira dificuldade de definição. No contexto dos debates recentes sobre um "retorno do eugenismo", certos autores propuseram restringir o termo a práticas coercitivas de controle da procriação ${ }^{22}$. Fazendo isso, evitar-se-ia aplicar uma palavra fortemente pejorativa a realidades contemporâneas, como o diagnóstico pré-natal e o aborto terapêutico. Mas justamente o procedimento que consiste em modificar uma definição para excluir um caso particular parece eminentemente criticável. Feita a abstração das nossas motivações

18 Cf. DARWIN, Ch. A origem do homem, p. 162: "exceto no caso do próprio homem, quase ninguém é tão ignorante a ponto de permitir aos seus piores animais se reproduzirem” (trad. modificada).

19 Cf. PICHOT, A. Id., p. 1.

20 Ibid., p. 25-26.

21 Cf. PAUL, D. Controlling Human Heredity..., p. 4.

22 Ibid., p. 4. 
Salanskis, E.

axiológicas atuais, é claro que Galton defendeu uma seleção artificial não coercitiva, ao mesmo tempo no domínio da eugenia dita "positiva" e no domínio da eugenia dita "negativa"23. Em seu artigo de 1865, ele imagina uma sociedade utópica em que seriam outorgados recursos aos casais mais meritórios. E ele defende nas Inquiries uma forma "clemente" de eugenia que provocaria a extinção das raças inferiores de maneira gradual, sem violência estatal ${ }^{24}$. Pode-se evidentemente duvidar que tais meios teriam sido apropriados ao fim perseguido. Todavia, uma definição que exclui o próprio inventor do termo parece insustentável. Além disso, é preciso acrescentar, na mesma ordem de ideias, que as legislações eugenistas não foram sistematicamente coercitivas. Na Dinamarca, por exemplo, uma primeira lei de esterilização, repousando no voluntariado, foi instaurada em 1926. Um de seus inspiradores, Karl Kristian Steincke, declarava em 1920 querer "melhorar a raça pelo que se denomina eugenia"25. Pareceria mais uma vez arbitrário rejeitar por definição um exemplo em que a palavra "eugenia" foi efetivamente reivindicada.

Resta-nos um último ponto a evocar, concernente à dimensão política do eugenismo. Certos autores pouco instruídos sobre a história da biologia sugeriram que ele teria sido o apanágio de pensadores reacionários. Assim, Domenico Losurdo acredita completar seu retrato de um Nietzsche "filósofo reacionário" citando

23 Sobre essa distinção convencional surgida no início do século 20, cf. GAYON, J. Le mot 'eugénisme' est-il encore d'actualité? Op. cit., p. 125-126. A eugenia positiva visa favorecer a reprodução de indivíduos julgados mais bem dotados ou a transmissão hereditária de caracteres desejáveis. A eugenia negativa, inversamente, procura prevenir a reprodução de indivíduos tidos por deficientes ou a transmissão de deficiências hereditárias.

24 Cf., respectivamente, GALTON, F. Hereditary Talent and Character. Op. cit., p. 165, e Inquiries..., p. 307-309. Nós traduzimos "merciful" por "clemente".

25 Cf. PAUL, D. Controlling Human Heredity..., p. 88-90. Diane Paul nota que a cláusula de voluntariado poderia não ter sido uma grande restrição do ponto de vista prático. Ela foi, por outro lado, suprimida a partir de 1934. Mas geralmente se incorre em engano quando se pensa que as coisas não poderiam ter sido piores. 
vários textos que propõem medidas de eugenia negativa ${ }^{26}$. Mas uma tal apresentação repousa em um preconceito retrospectivo. Com efeito, não apenas o eugenismo pós-darwiniano nasceu de uma forma de progressismo, mas ele teria sido inconcebível sem ela. Relembremos as próprias palavras de Galton em 1883: melhorar as linhagens humanas, promover os fins da evolução, causar "menos sofrimentos do que se os acontecimentos fossem deixados ao seu próprio curso". Galton não é de modo algum um exemplo isolado a esse respeito. Para compreendê-lo, é preciso considerar a natureza particular do progressismo que a teoria darwiniana promoveu.

Darwin acreditava no progresso evolutivo antes de desenvolver seu princípio de seleção natural. Ele se representava a progressão como uma complexificação crescente, isto é, à maneira de seus contemporâneos lamarckianos ${ }^{27}$. Mas a seleção natural implica uma concepção mais relativa do progresso, enquanto adaptação superior a um dado ambiente. Por essa razão, em A origem das espécies se assiste a uma tentativa de aproximação de dois conceitos de progresso. Com efeito, Darwin sugere que a progressão relativa da adaptação poderia explicar, em uma certa medida, o sentimento que nós temos de uma progressão transversal da complexidade ${ }^{28}$. Todavia, o progresso evolutivo se torna assim uma hipótese suscetível de ser refutada pela experiência. Trata-se de um progressismo contingente muito diferente daquele de Spencer, dado que ele depende não de uma lei cosmológica, mas do sucesso relativo dos organismos complexos na luta pela existência. E, de fato, Darwin escreve em

26 Cf. LOSURDO, D. Nietzsche philosophe réactionnaire. Pour une biographie politique. Trad.

A. Monville/ L.-A. Sanchi, Paris: Delga, 2007, p. 102-105.

27 Cf. RUSE, M. Monad to Man: The Concept of Progress in Evolutionary Biology. Harvard University Press, 2009, p. 145. O título do livro de Ruse, "da mônada ao homem", faz referência a esse conceito transversal de progresso enquanto complexificação orgânica. Darwin raciocina como lamarckiano em várias passagens importantes do caderno B: cf., em particular, DARWIN, Ch. Notebook B: Transmutation of species (1837-1838), p. 18 e p. 108-109.

28 Cf. DARWIN, Ch. A origem das espécies através da selecção natural ou a preservação das raças favorecidas na luta pela sobrevivência. Trad. Ana Alfonso. Leça da Palmeira: Planeta Vivo, 2009, p. 316. 
Salanskis, E.

A origem do homem que uma regressão evolutiva de nossa espécie é possível se a "classe dos melhores homens" se reproduz menos rapidamente do que os "membros inferiores da sociedade" 29 . "Devemos recordar-nos de que o progresso não é uma regra invariável", diz ele claramente a esse propósito ${ }^{30}$. $\mathrm{O}$ eugenismo pós-darwiniano está fundado na ideia de que a civilização moderna coloca em perigo o progresso biológico: os "fracos" bem poderiam predominar sobre os "fortes" em um contexto social anormalmente protegido. O vínculo entre eugenismo e progressismo é, portanto, crucial do ponto de vista dos fundamentos teóricos. Mas ele não é menos marcante, se se considera a questão em uma perspectiva mais sociológica. Certamente não se trata de acaso se as primeiras leis eugenistas foram adotadas nos Estados Unidos em um período denominado pelos historiadores "The progressive Era", "a era progressista" ${ }^{31}$. Esse exemplo deve nos lembrar que o eugenismo era frequentemente pregado em nome da ciência e do progresso. É isso que Aldous Huxley, irmão do biólogo eugenista Julian Huxley, mostrou de modo notável em Admirável mundo novo ${ }^{32}$.

Ao término dessas observações, podemos definir a eugenia como um controle social da reprodução a serviço de uma imagem normativa do homem. $\mathrm{O}$ eugenismo é a ideologia política que preconiza esse tipo de medidas, sejam elas coercitivas ou simplesmente incitativas, para melhorar linhagens humanas ou para impedir sua deterioração. Para nós, a questão consistirá em saber se Nietzsche pode ser qualificado como eugenista nesse sentido.

29 Cf. DARWIN, Ch. A origem do homem, p. 169. As faculdades intelectuais e morais são tratadas por Darwin como um equivalente humano da complexidade orgânica. Nietzsche retoma esse quadro de reflexão em um dos fragmentos "Anti-Darwin" de 1888: cf. Nachlass/ FP, 14[123], KSA 13.303.

30 Cf. DARWIN, Ch. A origem do homem, p. 169.

31 Cf. PAUL, D. Controlling Human Heredity..., p. 77-78.

32 Sobre Julian Huxley, cf. PICHOT, A. Id., p. 19-20.

176 | cadernos Nietzsche 32, 2013 


\section{Argumentos em favor de um eugenismo nietzschiano}

Esta segunda parte apresentará nossos principais argumentos em favor da existência de um eugenismo nietzschiano: a presença de textos explicitamente eugenistas no corpus, o interesse de Nietzsche por Galton e por outras fontes eugenistas pós-darwinianas, as considerações do filósofo sobre o casamento, a influência de Platão sobre seu pensamento político, enfim, a maneira pela qual a "grande política" é definida a partir de Para além de bem e mal. $\mathrm{O}$ argumento dos textos e o argumento das fontes serão privilegiados no quadro deste artigo, o que significa que não trataremos em detalhe os outros pontos e nos limitaremos a observações pontuais ${ }^{33}$. Por outro lado, na terceira seção nós nos deteremos no exame de certas objeções filosóficas que foram opostas a nossa interpretação. Elas nos ajudarão a refinar nossa compreensão da posição de Nietzsche, que é, sem dúvida, singular no contexto do eugenismo fin de siècle europeu.

\section{Os textos}

O nosso argumento primeiro e fundamental é que Nietzsche escreveu textos expressamente eugenistas. Parece-nos que a maioria dos comentadores que contestam a ideia de um eugenismo nietzschiano se abstém de citar ou de explicar os textos que nós vamos evocar. Porém, uma interpretação que não leva em conta todos os documentos se revela, por isso, insuficiente. Consideremos, desse ponto de vista, um dos fragmentos póstumos de 1888 mais radicais em matéria de eugenia negativa, o qual se intitula "Outro mandamento da filantropia" (Auch ein Gebot der Menschenliebe):

33 Para um tratamento mais desenvolvido, cf. SALANSKIS, E. La dimension eugéniste de la "grande politique" de Nietzsche. Op. cit., p. 163-178. 
A sociedade, como grande mandatária da vida, tem de responder por toda vida malograda diante da vida mesma, - ela tem também que expiá-la: ela deve, por conseguinte, impedi-la. A sociedade deve prevenir a procriação em numerosos casos: para isso, ela tem o direito de, sem consideração de proveniência, posição e espírito, ter à disposição as mais duras medidas de coação, privações de liberdade e, em certas circunstâncias, castrações. - A proibição bíblica "não matarás!" é uma ingenuidade em comparação com a seriedade da proibição de viver dirigida aos décadents: “não procriareis!"'.. A própria vida não reconhece nenhuma solidariedade, nenhum "direito igual" entre partes sadias e partes degeneradas de um organismo: devem-se amputar essas últimas - ou o todo perece. - Compaixão para com os décadents, direitos iguais também para os malogrados - isso seria a mais profunda imoralidade, isso seria a própria contranatureza como moral! (Nachlass/FP 1888, 23[1], KSA 13.599-600) $)^{34}$.

Não se pode negar que Nietzsche legitima aqui a exclusão reprodutiva de numerosos indivíduos, qualificados de decadentes ou de degenerados. A palavra "Castrationen" figura literalmente no texto alemão, mesmo se ela é precedida pela cláusula "unter Umständen", "em certas circunstâncias". Além disso, exige-se que a sociedade exerça esse controle da procriação, de um modo manifestamente coercitivo. E, em terceiro lugar, a finalidade de um tal procedimento reside em uma imagem normativa da vida humana, já que se trata de impedir toda degenerescência do organismo social. A definição de uma eugenia negativa dada no final da primeira parte se aplica, portanto, em todos os seus aspectos. Notemos, aliás, que o título do fragmento constitui igualmente um empréstimo à

34 Segundo a edição Colli-Montinari, esse fragmento data de outubro de 1888. Ele é, portanto, anterior ao envio do manuscrito de Ecce homo a Naumann. Ver igualmente dois fragmentos muito similares datados da primavera de 1888: Nachlass / FP 1888, 15[3], KSA 13.401-402, e 15[13], KSA 13.412-414. 
ideologia eugenista, na medida em que o argumento da filantropia é regularmente evocado por Galton e por seus discípulos ${ }^{35}$.

Poder-se-ia objetar que esse texto é apenas um fragmento póstumo, cujo alcance deve, por isso, ser relativizado. Se Nietzsche jamais houvesse publicado tais preconizações, estar-se-ia no direito de ver nisso uma simples atitude pessoal, sem vínculo direto com sua filosofia. Mas os escritos de 1888 não corroboram essa hipótese. Na verdade, existem três textos publicados que claramente fazem eco ao fragmento acima, ainda que eles não detalhem tão concretamente as medidas a serem adotadas ${ }^{36}$. Nesta seção, focalizaremos duas passagens que figuram respectivamente em Ecce homo e $O$ anticristo, reservando à seção seguinte a "moral para médicos" do Crepúsculo dos ídolos.

$\mathrm{O}$ fragmento 23[1] justifica a eugenia negativa como uma exigência fisiológica: a saúde de um organismo exigiria a amputação de seus membros degenerados. Ora, é precisamente essa justificação que se vê ressurgir em Ecce homo, no momento em que Nietzsche apresenta a "campanha contra a moral" que ele começou com Aurora:

Quando, no interior do organismo, o órgão mais insignificante descura, mesmo por um mínimo, de impor com total segurança sua autoconservação, sua renovação de forças, seu 'egoísmo', o todo degenera. O fisiólogo exige a amputação da parte degenerada, ele nega qualquer solidariedade ao degenerado, está o mais longe possível da compaixão por ele. Mas o sacerdote quer exatamente a degeneração do todo, da

35 Cf. supra, p. 4, e PICHOT, A. Id., p. 19-20. Referindo-se a Galton, Julian Huxley escreverá em 1941 em Man stands alone: “A eugenia não é meramente uma saída sã para o altruísmo humano, mas, entre todas as saídas para o altruísmo, aquela que é a mais geral e a de maior alcance" (Cf. HUXLEY, J. Man stands alone. New York: Harper, 1941, p. 34).

36 Cf. GD/CI, Incursões de um extemporâneo 36, KSA 6.134; EH/EH, Aurora 2, KSA 6.331, e AC/AC, $O$ anticristo 2, KSA 6.170. Nós retornaremos na terceira parte a essa diferença característica de precisão entre os textos publicados e os fragmentos póstumos. 
Salanskis, E.

humanidade: por isso conserva o que degenera - a este preço ele a domina (EH/EH, Aurora 2, KSA 6.331) ${ }^{37}$.

Essa passagem constrói a mesma oposição entre a moral cristã e a fisiologia que no fragmento 23[1]. A ideia de que a caridade cristã contraria a lei natural da vida constitui, notemo-lo, um lugar comum na literatura darwinista do século 19: nós a encontramos expressa ao menos em Galton, em William Greg e no próprio Darwin ${ }^{38}$. Todavia, quando Nietzsche exige que se "amputem" os membros degenerados da sociedade, ele vai mais longe no intervencionismo do que a maior parte dos eugenistas darwinianos, para retomar por sua conta as recomendações mais inquietantes do eugenismo psiquiátrico. $\mathrm{Na}$ seção seguinte, mostraremos a proximidade entre o discurso nietzschiano e o do psiquiatra francês Charles Féré.

O parágrafo 2 de $O$ anticristo é um segundo texto publicado que se situa na continuidade do fragmento 23[1]. Com efeito, naquele parágrafo Nietzsche incita a uma eliminação ativa dos fracos e dos malogrados, em nome de uma filantropia paradoxal que se opõe à piedade cristã:

Os fracos e malogrados devem perecer: primeiro princípio de nossa filantropia. E deve-se ajudá-los nisso.

O que é mais nocivo que qualquer vício? - A ativa compaixão por todos os malogrados e fracos - o cristianismo (AC/AC 2, KSA 6.170) ${ }^{39}$.

37 Trad. modificada Paulo César de Souza.

38 Darwin se recusa, no entanto, a retirar consequências eugenistas disso. Cf., respectivamente, GALTON, F. Hereditary Talent and Character. Op. cit., p. 326 e Inquiries..., p. 336; GREG, W. On the failure of "Natural Selection" in the case of Man. In: Fraser's Magazine, Sept. 1868, p. 353-362; DARWIN, Ch. A origem do homem, p. 169. Na terceira parte, nós analisaremos de maneira mais minuciosa a posição de Darwin a fim de confrontá-la com a reflexão maquiaveliana de Nietzsche.

39 Trad. modificada Paulo César de Souza. 
Essa formulação, é verdade, envolve com um véu de ambiguidade os meios concretos para ajudar os fracos a perecer. Mas Nietzsche deseja visivelmente mais do que um simples retorno ao laissez-faire, tal como o preconizam, por exemplo, Spencer e os darwinistas sociais. A aproximação com os dois textos precedentes parece impor-se, dadas a vizinhança cronológica e as similitudes temáticas. Nesse sentido, ajudar os fracos a desaparecer significaria notadamente impedi-los de se reproduzir ${ }^{40}$. Se essa interpretação é exata, o último Nietzsche não considera a doutrina do eterno retorno como um instrumento de seleção suficiente e, por isso, associa-lhe um projeto eugenista no sentido técnico do termo ${ }^{41}$.

Falamos há pouco em último Nietzsche, o que supõe uma periodização implícita da obra nietzschiana. Uma segunda objeção possível seria que o eugenismo constitui em Nietzsche um descaminho tardio: em outros termos, uma tomada de posição sem equivalente nos escritos intermediários e nas obras de maturidade. Mas Gregory Moore mostrou que essa sugestão não resiste ao exame ${ }^{42}$. Nietzsche imaginava desde 1876 um futuro em que se favoreceria a extinção das "raças ruins" para proceder à "criação das melhores"

40 Isso é compatível com o recurso a outros instrumentos mais culturais para excluir os fracos, como o pensamento do eterno retorno. Sabe-se que Nietzsche apresentou essa doutrina como seu "grande pensamento criador" (der große züchtende Gedanke) em vários fragmentos póstumos de 1884: cf. Nachlass / FP 1884, 25[211], KSA 11.69, 25[227], KSA 11.73, 26[376], KSA 11.250. Com isso, ele queria notadamente dizer que esse pensamento "dá a muitos o direito de se suprimirem" (25[227]) e que "as raças que não o suportam estão condenadas" (26[376]): o que tornaria possível uma forma de eugenia não coercitiva, no domínio cultural, que de algum modo levaria os fracos ao suicídio. O que quer que se pense sobre esse projeto, Nietzsche ultrapassa os seus limites em vários textos de 1888 nos quais ele não descarta a ideia de uma coerção eugenista. Sobre o eterno retorno enquanto pensamento seletivo, cf. WOTLING, P. Nietzsche et le problème de la civilisation. Paris: PUF, 1995, p. 353-382.

41 Sobre esse ponto, nós não partilhamos a leitura de Éric Blondel em sua edição de $O$ anticristo (cf. NIETZSCHE, F. L'Antéchrist. Trad.: É. Blondel, Paris: GF Flammarion, 1994, nota 19, p. 138-139). Segundo Éric Blondel, nessa passagem Nietzsche falaria apenas em sentido abstrato ou metafórico, de modo que "não [seria] questão de eugenismo em ato". Mas pode-se compreender a amputação preconizada em Ecce homo como uma simples metáfora? E a mesma observação se aplicaria a fortiori às castrações evocadas no fragmento 23[1].

42 Cf. MOORE, G. Nietzsche, Biology and Metaphor. Op. cit., p. 135. 
(Nachlass / FP 1876, 19[79], KSA 8.349). E, sem rodeios, ele acrescentava que "a extinção de muitas espécies de homens é tão desejável quanto qualquer reprodução" (Nachlass / FP 1880, 5[38], KSA 9.189). Apesar da equivocidade da palavra alemã Aussterbenlassen, que pode significar "fazer extinguir" ou "deixar extinguir", nosso filósofo não recuava diante dos procedimentos coercitivos. Testemunha-o uma comparação que ele sugere entre os indivíduos sem escrúpulos e as crianças malformadas, a fim de justificar uma biopolítica impiedosa: "Contra tais indivíduos, o resto da humanidade tem os mesmos direitos do que contra as crianças malformadas e os monstros: é-lhe permitido destruí-los, para não favorecer a propagação do que é retardado e malogrado" (Nachlass / FP 1876, 23[59], KSA 8.424) ${ }^{43}$. Aqui, como se vê, a eugenia se aparenta à eutanásia, como será o caso em A gaia ciência - que legitima a eutanásia das crianças debilitadas sob o título "Santa crueldade" (FW/GC 73, KSA 3.430).

À luz desses textos, não se pode dizer que o eugenismo aparece tardiamente no pensamento de Nietzsche. Certamente ele não ocupa o mesmo lugar na época de Humano, demasiado humano, em uma filosofia que reivindica uma certa abstinência política, e na época de Para além de bem e mal, quando Nietzsche traça sua perspectiva de uma "grande política" europeia. Mas essa grande política não surge ex nihilo durante o último período. O que se produz a partir de 1886 é no máximo uma mudança de plano e uma radicalização.

O discurso de Nietzsche acerca da extinção de variedades humanas nos obriga a meditar sobre uma realidade histórica em parte esquecida. A ideia de um extermínio futuro das raças ou dos indivíduos inferiores não era tabu para os pensadores evolucionistas do século 19, inclusive para os mais progressistas, como Darwin e Wallace $^{44}$. Seria um engano acusá-los sistematicamente de racismo:

43 Segundo esse fragmento, o exemplo típico de um tal indivíduo malformado é o assassino. No entanto, Nietzsche quer estender a categoria de malformação para além desse caso particular. 44 Cf. DARWIN, Ch. A origem do homem, p. 188, e WALLACE, A. The Origin of Human 
Darwin considerava esse processo somente como um resultado necessário da luta pela existência ${ }^{45}$. Ao exumar declarações de Nietzsche moralmente chocantes de um ponto de vista contemporâneo, não pretendemos de modo algum fazer dele um bode expiatório. $\mathrm{O}$ mesmo tipo de trabalho poderia ser feito acerca de numerosos médicos, biólogos e filósofos, sejam eles evolucionistas ou simplesmente transformistas - isto é, influenciados pelo pensamento de Lamarck antes da publicação de $A$ origem das espécies (1859). De fato, um precedente significativo para Nietzsche é o de Schopenhauer, que aventa a ideia de uma eugenia coercitiva desde 1844, portanto bem antes de Darwin e Galton, em um suplemento ao Mundo como vontade e representação inspirado em Platão ${ }^{46}$. O que faz de Nietzsche um caso particular nesse contexto é a radicalidade com a qual ele se empenha para justificar seu eugenismo. Assim como sobre outros assuntos, uma crítica ao autor de Assim falava Zaratustra a respeito desse ponto não pode ignorar a acuidade de sua reflexão filosófica. É, em todo caso, o que nós nos esforçaremos para mostrar na terceira parte.

\section{As fontes}

Antes, devemos abordar um segundo argumento essencial em favor da existência de um eugenismo nietzschiano, o fato de que Nietzsche se refere a partidários contemporâneos dessa ideologia.

\footnotetext{
Races and the Antiquity of Man Deduced from the Theory of "Natural Selection". In: Journal of the Anthropological Society of London. Vol. 2., 1864, p. clviii-clxxxvii, especialmente p. clxix.

45 Cf. TORT, P. L'Effet Darwin. Op. cit., p. 72-73. De maneira geral, é imperativo distinguir entre o racialismo, a concepção antropológica que reconhece a existência de raças humanas enquanto tipos psicobiológicos hereditários, e o racismo, que incita à violência ou à discriminação de raças particulares. O primeiro não implica necessariamente o segundo.

46 Cf. Schopenhauer, A. Sämtliche Werke, Leipzig: Brockhaus, 1873, 3. Band, Die Welt als Wille und Vorstellung, Ergänzungen zum vierten Buch, §43 p. 604. (A página em questão foi dobrada como referência na edição pessoal de Nietzsche, provável sinal de interesse).
} 
Salanskis, E.

A esse propósito, daremos dois exemplos que ilustram as duas principais correntes do eugenismo na virada do século 20: a corrente biológica e a corrente psiquiátrica.

Já apresentamos Francis Galton, indicando em que circunstâncias Nietzsche foi levado a lê-lo ${ }^{47}$. Mas não é toda leitura que necessariamente exerce uma influência. Resta a estabelecer que a leitura do cientista inglês efetivamente desempenhou um papel na reflexão de Nietzsche. Esse trabalho foi parcialmente realizado por Marie-Luise Haase a partir de quatro capítulos das Inquiries intensamente trabalhados por Nietzsche e compilados nos fragmentos póstumos ${ }^{48}$. Todavia, os capítulos em questão não tratam diretamente do eugenismo, ainda que eles também sejam subordinados ao grande projeto de Galton ${ }^{49}$. E uma dificuldade suplementar é que Nietzsche pronuncia expressamente o nome de Galton apenas em sua correspondência ${ }^{50}$. Por isso, proporemos uma abordagem específica do problema a partir de dois testemunhos pessoais. Esses testemunhos, porque eles tratam do momento em que Nietzsche descobre as Inquiries, permitem colocar em relação o pensamento nietzschiano da criação com a eugenia galtoniana.

O primeiro testemunho é o de Resa von Schirnhofer, uma amiga de Malwida von Meysenbug que narrou em suas memórias um encontro com Nietzsche em abril de $1884^{51}$. Pouco antes dessa ocasião, o filósofo se fizera oferecer as Inquiries de Galton. Ele apresenta a obra como uma contribuição ao estudo da hereditariedade e da evolução "em relação com Darwin e em refutação parcial de suas teorias" ${ }^{" 52}$. Visivelmente Nietzsche leu o texto com atenção

47 Cf. supra, p. 3.

48 HAASE, M.-L. Friedrich Nietzsche liest Francis Galton. Op. cit., p. 637 ss.

49 Ibid., p. 636-637.

50 Cf. as cartas a Overbeck, de 4 de julho de 1888 (KSB 8.346-348), e a Strindberg, de 8 de dezembro de 1888 (KSB 8.508).

51 Cf. SCHIRNHOFER (von), R. Vom Menschen Nietzsche. In: Zeitschrift für philosophische Forschung, n.22, vol. 2, p. 250-260,1968.

52 Ibid., p. 256 : "Während ich im Buch blätterte, [...], erläuterte mir Nietzsche in Grundzügen

184 | cadernos Nietzsche 32,2013 
e não esconde sua admiração. Mas, dado que mais de uma vez ele revisou sua opinião sobre autores que estimava, isso não seria em si um índice suficiente. Isso nos conduz ao segundo testemunho, o de Josef Paneth, que emprestou e depois ofereceu o livro de Galton a Nietzsche em março de 1884, e que relata as conversas de ambos a esse respeito. É sobre o princípio de uma criação do homem que Nietzsche e Paneth estão em desacordo: se Nietzsche o defende, Paneth objeta "que não existe ninguém que tenha o direito de reinar sobre o homem como o criador de bovinos reina sobre seus bovinos e que esse fim não pode ser definido"53. Essa conversa mostra bem que Nietzsche não tem nenhuma objeção de princípio contra uma criação humana compreendida no sentido zoológico. Ao contrário, veremos na terceira parte que ele procura justificar esse projeto de maneira consequencialista. A sequência do relato de Paneth lança luz sobre a face negativa da criação nietzschiana. Paneth desempenha de uma certa maneira o papel de advogado do diabo, observando que certas instituições humanas poderiam entravar a luta pela existência, proteger os fracos e assim "deteriorar a raça". Sem contestar essa análise, Nietzsche "ao contrário concordou inteiramente e disse que isso ainda era um resto de cristianismo, com seu desprezo a tudo o que serve e convém a esse mundo" ${ }^{\circ 4}$. Nessa resposta se reconhece a crítica à compaixão cristã que, associada à exclusão reprodutiva dos fracos, caracteriza os textos de 1888 precedentemente citados.

die darin behandelten Probleme und errungenen Resultate auf dem Gebiet der Vererbung und Entwicklung im Anschluss an Darwin und in teilweiser Widerlegung seiner Theorien. Nach diesem fesselnden Privätissimum über das Werk dieses von ihm sehr bewunderten englischen Forschers, nahm er das Buch wieder an sich". Sobre as razões pelas quais Nietzsche julga que Galton refuta parcialmente Darwin, cf. SALANSKIS, E. La dimension eugéniste de la "grande politique" de Nietzsche. Op. cit., p. 172-175.

53 Cf. FRANK KRUMMEL, R. Joseph Paneth über seine Begegnung mit Nietzsche in der Zarathustra-Zeit". Op. cit., p. 490.

54 Ibid. 
Salanskis, E.

Podemos agora identificar vários sinais de uma influência de Galton nos escritos posteriores a março de 1884. Nietzsche recorre à palavra "criador" (Züchter) nos livros III e IV de Assim falava Zaratustra, publicados em abril de 1884 e em maio de 1885, para designar Zaratustra e a "nova nobreza" por esse último consagrada (ZA/ZA III, De velhas e novas tábuas 12, KSA 4.254, ZA/ZA IV, A oferenda do mel, KSA 4.297). O mesmo termo será em seguida aplicado ao filósofo em Para além de bem e mal (JGB/BM 207, KSA 5.163). Um título provisório considerado para Para além de bem e mal era justamente: " $O$ s bons europeus. Proposições para a criação de uma nova nobreza" (Nachlass / FP 1884, 26[320], KSA 11.234).

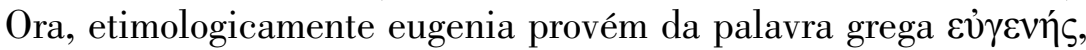
que significa "de origem nobre", um fato ao qual um antigo filólogo tal como Nietzsche teria sido sensível. É lógico, portanto, que Para além de bem e mal defina o problema europeu como a "criação de uma nova casta que governe a Europa" (JGB/BM 251, KSA 5.195) ${ }^{55}$. É preciso também prestar atenção às proposições concretas do livro nesse sentido, notadamente no parágrafo 251 , em que se trata de "juntar por criação" (hinzuzuichten) o gênio judeu às qualidades hereditárias do oficial prussiano ${ }^{56}$. Nietzsche introduz assim sua própria eugenia positiva, colocando a procriação a serviço do engendramento de indivíduos mais bem dotados ${ }^{57}$. A ideia de uma criação aditiva ou combinatória parece, ela também, diretamente

55 Trad. modificada Paulo César de Souza.

56 Às vezes se quis ver nessa sugestão um simples traço de ironia. Mas uma tal leitura é tornada pouco provável por um fragmento póstumo de 1885 que já levanta o "problema de uma miscigenação da aristocracia europeia ou antes do junker prussiano com judias" (cf. Nachlass / FP 1885, 36[45], KSA 11.569). Um assunto de pilhéria não seria apresentado como um problema em um fragmento aproximadamente contemporâneo. Além disso, uma oposição demasiadamente rígida entre pilhéria e seriedade não dá conta da posição de discurso de Nietzsche, que é mais adequadamente descrita pela fórmula "ridendo dicere severum" (adaptada, no início de $O$ caso Wagner, do "ridendo dicere verum", de Horácio).

57 Conforme uma máxima de Zaratustra: "Nicht nur fort sollst du dich pflanzen, sondern hinauf! Dazu helfe dir der Garten der Ehe!” (ZA/ZA I, Dos filhos e do matrimônio, KSA 4.90). 
inspirada nas técnicas de cruzamento e de superposição fotográfica de Galton ${ }^{58}$. Este aparece claramente como uma fonte de Nietzsche quando todos esses elementos são reunidos.

A outra fonte eugenista que evocaremos é o psiquiatra francês Charles Féré. Colaborador de Charcot na Salpêtrière, ele é o autor de Degenerescência e criminalidade, uma obra publicada em 1888 que figura na biblioteca de Nietzsche ${ }^{59}$. Como Charcot, Féré adere à teoria psiquiátrica da degenerescência: é sua concepção hereditarista das patologias mentais que o leva a preconizar uma intervenção biopolítica. Em sua diatribe contra "os nocivos", no capítulo $\mathrm{X}$, ele prescreve um controle social da reprodução que recusaria qualquer solidariedade aos degenerados:

[...] o corpo humano sobrevive apenas quando todos os seus órgãos são bem constituídos e estão em plena saúde; se um deles sofreu uma alteração qualquer, o conjunto sofre, e frequentemente se segue a morte. Quando uma parte do corpo é a sede de uma desorganização profunda, obtém-se a cura somente pela eliminação da parte doente. Nesse processo, não há base fisiológica para o princípio de fraternidade, tal como às vezes ele é compreendido ${ }^{60}$.

Comparando essa citação ao fragmento 23[1], percebe-se que Nietzsche se inspirou em Féré para escrever seu texto ${ }^{61}$. Os argumentos e as conclusões são os mesmos: Féré já preconiza a amputação dos indivíduos degenerados, ele evoca a fisiologia de modo

58 Cf. SALANSKIS, E. La dimension eugéniste de la "grande politique" de Nietzsche. Op. cit., p. 177-178. Nietzsche defende, por outro lado, uma eugenia europeia muito diferente do projeto nacionalista de Galton.

59 Cf. FÉRÉ, Ch. Dégénérescence et criminalité. Essai physiologique. Paris: Félix Alcan, 1888. A obra porta o código C247 na Herzogin Anna Amalia Bibliothek.

60 Ibid., p. 106.

61 Assim como, de resto, os fragmentos 15[3] e 15[13], indicados precedentemente em nota.

Para uma comparação mais sistemática entre extratos de Féré e de Nietzsche, cf. LAMPL, H.-E. Ex oblivione: Das Féré-Palimpsest. In: Nietzsche-Studien, n.15, p. 225-264, 1986. 
Salanskis, E.

semelhante, ele afirma igualmente que a compaixão moral seria contranatural nessa circunstância ${ }^{62}$. Essa referência psiquiátrica poderia explicar que a eugenia do último Nietzsche visa notadamente os neurastênicos e os sifilíticos, duas categorias mais estritamente medicais do que a de decadência ${ }^{63}$. Além disso, a lembrança de Féré parece também subjacente ao tema da criminalidade degenerada, tal como ele surge, por exemplo, quando Nietzsche afirma que "há casos em que um filho seria um crime" (Nachlass / FP 1888, 23[1], KSA 13.599).

Convém sublinhar a esse respeito o papel dos psiquiatras na difusão de um eugenismo frequentemente mais radical do que aquele dos biólogos. Professando uma concepção fatalista da hereditariedade patológica, a psiquiatria da degenerescência preconizava de maneira coerente políticas de exclusão reprodutiva ${ }^{64}$. Ela contribuiu assim para uma medicalização da eugenia que levou ao terrível conceito de higiene racial ${ }^{65}$. A história do eugenismo ganharia ao tomar em consideração essa corrente psiquiátrica que, embora evolucionista, não se reduz à corrente genética fundada por Galton.

Deve-se achar surpreendente que Nietzsche tenha sido sensível a tais temáticas? Não podemos concluir esta seção sem indicar uma

62 Cf. FÉRÉ, Ch. Dégénérescence et criminalité. Op. cit., p. 104.

63 O fragmento 23[1] tem por alvo os "doentes crônicos e neurastênicos de terceiro grau" (KSA 13.599), o fragmento 15[3] acrescenta os sifilíticos (KSA 13.402). Féré inclui justamente os neurastênicos e os sifilíticos em seu amplo conceito de "decadentes de toda ordem" (Dégénérescence et criminalité. Op. cit. p. 103). Precisemos que os psiquiatras franceses tendiam na época a interpretar a sífilis congênita como uma "heredossífilis", razão pela qual eles consideravam a sífilis como uma doença hereditária: cf. CORBIN, A. L'hérédosyphilis ou l'impossible rédemption. Contribution à l'histoire de l'hérédité morbide. In: Romantisme, n.31, p. 131-150, 1981. Hoje se sabe que a sífilis congênita resulta de uma contaminação do feto através da barreira placentária. Na falta dessa informação, Nietzsche tinha boas razões para escrever: "O sifilítico que faz um filho é a causa de toda uma cadeia de vida malograda" (Nachlass / FP 1888, 15[3], KSA 13.402). A questão de saber se o próprio Nietzsche estava acometido por sífilis dá, por outro lado, uma dimensão suplementar a essa nota.

64 Cf. CORBIN, A. L'hérédosyphilis ou l'impossible rédemption. Contribution à l'histoire de l'hérédité morbide. Op. cit., p. 149.

65 Esse conceito já está presente em Féré: cf. FÉRÉ, Ch. Dégénérescence et criminalité. Op. cit., p. 129-131. O livro fala mesmo em instaurar uma "polícia sanitária" da hereditariedade. 
fonte que, dissimulada sob as outras, explica o interesse precoce do filósofo pelo eugenismo. Trata-se evidentemente de $A$ República, de Platão. Dos cursos da Basiléia a $O$ anticristo, aquela aparece a Nietzsche como o modelo de uma biopolítica aristocrática ${ }^{66}$. Sem dúvida, o discurso de Féré não teria atraído sua atenção se ele não lhe tivesse lembrado um princípio platônico: a ideia de que o deus da medicina, Asclépio, não destinou sua arte aos homens "doentes por natureza" para médicos" do Crepúsculo dos ídolos, que nos convida a:

Criar uma nova responsabilidade, a do médico, para todos os casos em que o supremo interesse da vida, da vida ascendente, exige a mais implacável supressão e rejeição da vida que degenera - por exemplo, para os casos do direito à procriação, do direto de nascer, do direito de viver (GD/CI, Incursões de um extemporâneo 36, KSA 6.134) ${ }^{68} \ldots$

Que se interprete essa passagem no sentido de uma eugenia coercitiva ou de uma eutanásia ativa, a existência de um "palimpsesto Féré" sob os escritos de 1888 nos parece atestada. Isso obriga a inscrever Nietzsche na difícil história da emergência das eugenias de Estado - uma história que naturalmente começou com Platão.

\section{Objeções filosóficas}

Devemos examinar nesse momento várias objeções filosóficas contra a tese de um eugenismo nietzschiano. Introduziremos essa análise por um breve nota bene histórico. Como indicado na

66 Cf. CONSTANTINIDÈS, Y. Les législateurs de l'avenir. L'affinité des projets politiques de Platon et de Nietzsche. In : CRÉPON, M. (dir.), Nietzsche, Paris: Éditions de l'Herne, 2005, p. 128-143.

67 Cf. PLATÃO. A República, III, 405c-408b. O interlocutor de Sócrates, Glauco, declara a esse propósito em 407e: "É um Asclépio político que você descreve aqui".

68 Trad. Paulo César de Souza. 
Salanskis, E.

introdução, a história das recepções de Nietzsche conheceu uma ruptura sobre a questão do eugenismo depois de 1945. O regime nazista havia se apropriado da obra nietzschiana para legitimar sua política racial: era preciso então uma resposta unilateral, por sim ou por não, às interrogações sobre a responsabilidade do filósofo ${ }^{69}$. Walter Kaufmann foi, em 1950, o primeiro comentador a desenvolver uma argumentação detalhada para "desnazificar" Nietzsche. Não contestamos de modo algum os méritos desse trabalho, que permanece uma obra de referência dos estudos nietzschianos. Mas nos parece que, ao associar a questão do eugenismo à do nazismo, Kaufmann suscitou uma confusão entre esses dois pontos, que os comentadores apenas começam a superar ${ }^{70}$.

Assim, $o$ argumento mais recorrente para afastar o eugenismo permanece o de que Nietzsche não preconizou uma política de purificação racial ${ }^{71}$. Essa ressalva contradiz efetivamente as interpretações nazistas como as de Alfred Bäumler ou de Richard Oelher ${ }^{72}$. Contrariamente a esses autores, Nietzsche valoriza os cruzamentos raciais por razões ao mesmo tempo biológicas e culturais: para ele, os gregos são o exemplo de um povo mestiço que, integrando culturalmente sua diversidade, tirou dela uma pureza mais bela e mais forte $^{73}$. Talvez seja a partir desse modelo que Nietzsche imagina em 1886 casar oficiais prussianos e mulheres judias. Mas uma tal atitude constitui uma prova de antieugenismo apenas se se define a

69 Cf. ASCHHEIM, S. The Nietzsche Legacy in Germany 1890-1990, Op. cit., p. 232-271.

70 Cf. KAUFMANN, W. Nietzsche. Philosopher, Psychologist, Antichrist. Op. cit., p. 304-306. Kaufmann sustenta que a irmã de Nietzsche, Elisabeth Förster-Nietzsche, teria conferido uma importância artificial à noção de criação (Züchtung) no pensamento de seu irmão. Dado o antissemitismo de Elisabeth e suas simpatias ulteriores pelo nazismo, isso sugere que o preço a pagar para desnazificar Nietzsche é o de minorar a noção de Züchtung.

71 Cf. FREZZATTI JUNIOR, W. A. Nietzsche contra Darwin. São Paulo: Discurso Editorial, 2001, p. 103, nota 137, e p. 113-114.

72 Cf. KAUFMANN, W. Nietzsche. Philosopher, Psychologist, Antichrist. Op. cit., p. 284 e ss.

73 Cf. M/A 272, KSA 3.213, assim como Nachlass / FP 1875, 5[198], KSA 8.96 (sobre a mistura racial grega) e Nachlass / FP 1885, 1[153], KSA 12.45 (com a máxima: "Lá onde as raças são misturadas, a fonte de grande cultura"). 
eugenia como uma política de purificação racial. Porém, há aí uma petição de princípio, uma vez que Galton fala somente de "ciência da melhoria das linhagens", sem identificar a priori a melhoria com uma purificação ${ }^{74}$. A ambiguidade da palavra "melhoria" implica que uma eugenia dependa sempre de uma axiologia prévia. Se numerosos eugenistas militaram em favor de políticas de purificação racial, provavelmente é porque a pureza era um ideal cultural firmemente enraizado, e não porque a teoria da evolução o teria justificado ${ }^{75}$.

Uma segunda objeção importante é que Nietzsche não se preocupa com a evolução da humanidade em seu conjunto, mas apenas com a emergência de indivíduos superiores ${ }^{76}$. Inúmeros textos atestam de fato que a axiologia nietzschiana privilegia os indivíduos: "Um povo é o rodeio que faz a natureza para chegar a seis ou sete grandes homens", lê-se em Para além de bem e mal (JGB/BM 126, KSA 5.95) ${ }^{77}$. Todavia, fazer dessa consideração um argumento antieugenista parece duplamente problemático. Primeiramente, é mais uma vez pressupor uma definição redutora do eugenismo tendo como única escala a humanidade inteira. O raciocínio populacional permite, em Galton, pensar a eugenia em várias escalas ${ }^{78}$. Em segundo lugar, não é certo que Nietzsche conceba sua criação

74 Galton não vê no reforço do tipo médio senão "a direção mais fácil em que uma raça pode ser melhorada": cf. Inquiries..., p. 14.

75 A partir de uma reflexão sobre a fecundação das orquídeas, Darwin conjectura ao contrário "que um grande bem desconhecido decorre da união de indivíduos que foram mantidos separados por muitas gerações", cf. DARWIN, Ch. On the various contrivances by which British and foreign orchids are fertilised by insects, and on the good effects of intercrossing. London: John Murray, 1862, p. 360.

76 Cf. MOORE, G. Nietzsche, Biology and Metaphor. Op. cit., p. 136, e FREZZATTI JUNIOR, W. A. Nietzsche contra Darwin. Op. cit., p. 103, nota 137.

77 Trad. Paulo César de Souza. Segundo $O$ anticristo, o problema não é substituir uma outra espécie à humanidade, mas criar conscientemente um tipo superior de homens (AC/AC 3, KSA 6.170).

78 Galton pensa em melhorar, em um futuro próximo, a raça inglesa: cf. Inquiries..., p. 14 e p. 330-331. Para isso, ele deseja, ele também, criar uma aristocracia de indivíduos superiores. Cf. Hereditary Talent and Character. Op. cit., p. 166: "A capacidade intelectual geral de nossos dirigentes necessita ser elevada, e também ser diferenciada. Nós precisamos de comandantes, homens de estado, pensadores, inventores e artistas mais capazes". 
Salanskis, E.

independentemente de uma biopolítica mundial, que se exerceria sobre o conjunto da humanidade. Nos fragmentos póstumos, a criação é regularmente associada à perspectiva de um "governo da terra"79. Esse vínculo é confirmado pela maneira como Nietzsche define sua "grande política" em 1888: "a grande política quer fazer da fisiologia a senhora de todas as outras questões; ela quer gerar uma potência suficientemente forte para criar a humanidade como um todo e como uma entidade superior" (Nachlass / FP 1888, 25[1], KSA 13.637). Não vemos uma boa razão para opor uma problemática individual a uma problemática coletiva nesse contexto ${ }^{80}$. Enfim, levantou-se a objeção de que Nietzsche não utiliza a palavra "eugenia" razões. Por um lado, o termo tinha sido introduzido havia pouco, em 1883, e ainda não se impusera contra todos seus concorrentes, notadamente "seleção humana" 2 . Por outro lado, Nietzsche não costuma citar nomeadamente suas fontes contemporâneas, mesmo quando ele fez empréstimos importantes delas, como no caso de Friedrich-Albert Lange ou de Afrikan Spir. Nosso filósofo retém apenas os nomes que podem ser igualados aos dos autores clássicos. Portanto, ele certamente não teria prestado homenagem a Galton enquanto ele podia evocar Platão a título de predecessor. E, em terceiro lugar, Nietzsche é um filósofo que reconheceu a importância axiológica de falar sua própria linguagem. À diferença de Galton, ele recusa a moral progressista de seu tempo e não pode se satisfazer com todas as conotações da palavra "eugenia". Retomar

79 Cf. Nachlass / FP 1876, 19[79], KSA 8.349, 1881, 11[276], KSA 9.547-548, 1885, 35[74], KSA 11.541-542, 1885, 2[179], KSA 12.155. A Züchtung poderia ser indissociável de uma Erd-Regierung, na medida em que ela exige que as massas sejam sacrificadas a uma elite.

80 Desde os escritos do período da Basiléia, Nietzsche medita sobre a articulação entre a emergência do grande indivíduo e a vida de um povo ou de uma cultura. Cf., por exemplo, Nachlass / FP 1872, 19[33], KSA 7.426.

81 Cf. GAYON, J. Nietzsche and Darwin. Op. cit., p. 175-176. Precisemos que Jean Gayon cita essa objeção sem subscrevê-la.

82 Cf. WALLACE, A. R. Human Selection. In: Fortnightly Review, n.48, p. 325-337, 1890. 
esse termo com pretensão científica simplesmente não corresponde à sua estratégia filosófica.

\section{Eugenismo e maquiavelismo}

Abordaremos agora o difícil problema da justificação que Nietzsche pretende dar ao seu eugenismo. Na medida em que, para ele, a questão do valor não se reduz à da verdade, ele não pode, como os eugenistas darwinianos, fazer apelo a uma concepção científica. Ele deve então considerar a legitimação em uma perspectiva diferente, distinguindo mais nitidamente os fins e os meios. É aqui, parece-nos, que Nietzsche recorre a considerações maquiavelianas diretamente inspiradas no Príncipe.

Existe uma leitura mais simples e menos caridosa? Certamente os dois primeiros textos citados na segunda parte dão a impressão de se contentar com uma justificação sumária da eugenia negativa. Esta decorreria da evidência fisiológica, supondo-se que se queira assegurar a saúde do organismo social. Mas Nietzsche sabe melhor do que ninguém que a fisiologia constitui uma interpretação: lá onde ela tendia a postular um instinto de conservação, ele faz ver o desdobramento de uma vontade de potência (JGB/BM 13, KSA 5.27). Pode-se, pois, duvidar que o apelo à fisiologia seja a sua última palavra. A conversa com Paneth já mencionada sugere um horizonte axiológico mais longínquo:

[...] ele disse que era tão avançado e tão cético em relação aos problemas éticos, em relação à questão do que é bem e mal, que ele não poderia de modo algum dizê-lo, assustar-se-ia com isso; podiam-se representar um ponto de vista e metas pelos quais se deveriam reprimir seus bons movimentos, sua compaixão, tendo em vista um fim superior ${ }^{83}$.

83 Cf. FRANK KRUMMEL, R. Joseph Paneth über seine Begegnung mit Nietzsche in der Zarathustra-Zeit. Op. cit., p. 490. 
Reprimir seus bons movimentos e sua compaixão tendo em vista um fim superior: é a atitude que denominaremos o maquiavelismo de Nietzsche. Gostaríamos de mostrar, para terminar este artigo, que um tal maquiavelismo preside mesmo ao eugenismo nietzschiano.

Para isso, reportemo-nos a um fragmento póstumo de 1887 que contém um esboço de Tractatus politicus (Nachlass / FP 1887, 11[54], KSA 13.24-27). Nele, Nietzsche defende uma "política da virtude" que exige uma distinção radical entre o fim e os meios: para ele, querer a soberania da virtude implica por princípio renunciar a ser virtuoso. Uma tal dissociação é explicitamente reportada ao maquiavelismo:

Esse tratado tem por objeto, como mencionado, a política da virtude: ele estabelece um ideal dessa política, ele a descreve tal como ela deveria ser, se algo pudesse ser perfeito sobre essa terra. Hoje nenhum filósofo terá dúvida sobre o que é o tipo da perfeição em política; a saber, o maquiavelismo (ibid., KSA 13.25).

Nietzsche insiste longamente nessa ideia provocadora. O maquiavelismo puro não é jamais alcançado pelos homens, ele é no máximo tocado pelos "fundadores de novas potências morais" tais como Platão (ibid., KSA 13.26). E isso se deve ao fato de que nenhum moralista chega a tornar-se totalmente um "imoralista da ação". $\mathrm{O}$ desafio consistiria em "de maneira divina manter separados seu esse e seu operari", isto é, em trabalhar em favor de um ideal do qual se permaneceria, no entanto, livre e mestre no interior de si. " $\mathrm{Um}$ grande moralista é, entre outras coisas, necessariamente também um grande ator", declara Nietzsche sem rodeios (ibid., KSA 13.26).

Nota-se nesse desenvolvimento uma reminiscência do capítulo 18 do Príncipe, intitulado "Como os príncipes devem cumprir sua palavra"84. Maquiavel detalhou primeiramente as qualidades que o

84 Cf. MACHIAVEL, N. Le Prince. Trad.: C. Ferrari, Paris: Bibliothèque nationale, 1897.

194 | cadernos Nietzsche 32, 2013 
príncipe deve possuir ou ao menos parecer possuir. Ele alerta, todavia, do perigo que haveria, para um príncipe querendo conservar seu Estado, em ser absolutamente virtuoso:

Um príncipe não tem, portanto, necessidade de possuir todas as qualidades que eu indiquei, mas ele deve parecer tê-las. Eu acrescentaria mesmo que ter e servir-se dessas qualidades é perigoso, e que é sempre útil fingir tê-las; é assim que ele deve parecer clemente, fiel, humano, religioso e íntegro; mas ele deve permanecer suficientemente senhor de si para que, se necessário, ele possa e saiba fazer o contrário ${ }^{85}$.

Não procuraremos elucidar todas as razões pelas quais Maquiavel prescreve essa atitude. Retenhamos que ela procede de uma moral consequencialista, já que ela é justificada pelas consequências perigosas da atitude oposta. O príncipe maquiaveliano deve dominar as inclinações morais que conduziriam o Estado à ruína, desempenhar o papel da virtude sem deixar que ele se torne uma natureza. Nietzsche, que leu e releu $O$ Príncipe, aparece como um discípulo de Maquiavel nesse ponto ${ }^{86}$.

Esse maquiavelismo poderia estar na origem de uma certa dissimulação em que se envolvem os textos publicados no momento de evocar o eugenismo. Já destacamos um exemplo notável a esse respeito: "ajudar os fracos a perecer" é uma formulação enigmática, que Nietzsche poderia clarificar mencionando os meios concretos que ele considera em seus fragmentos póstumos. Mas, dado que ele se abstém de todo esclarecimento, é provável que ele não desejasse ser mais claro sobre esse ponto. Ele se dirige assim a leitores que saberão entrever suas intenções através das máscaras do imoralista.

Essa tradução francesa, publicada em 1873, é a que Nietzsche possuía em sua biblioteca pessoal: cf. DOMBOWSKY, D. Nietzsche's Machiavellian Politics. New York: Palgrave Macmillan, 2004, p. 199.

85 Cf. MACHIAVEL, N. Le Prince. Op. cit., p. 141.

86 Cf. DOMBOWSKY, D. Nietzsche’s Machiavellian Politics. Op. cit., p. 132 e p. 142. 
Salanskis, E.

A seção do Crepúsculo dos ídolos que tem por objeto "Os "melhoradores' da humanidade" ilustra bem essa estratégia. Nela, Nietzsche compara dois tipos de morais que pretenderam melhorar a humanidade no decorrer da história: uma moral do amansamento (Zähmung), que se exerceu nas sociedades cristãs, e uma moral da criação (Züchtung), da qual o sistema de castas hindu fornece um exemplo privilegiado. Esse sistema de castas é apresentado como uma instituição eugenista, na medida em que ele visa a criar "não menos que quatro raças" (GD/CI, Os "melhoradores" da humanidade 3, KSA 6.100. Trad. Paulo César de Souza). A questão consiste, por conseguinte, em saber se Nietzsche aspira a constituir uma organização social similar. Ora, de modo notável, a seção fornece sucessivamente índices pro e contra próprios para desconcertar um leitor apressado. Nietzsche descreve primeiramente os autores das Leis de Manu como "uma espécie de homem cem vezes mais branda e mais razoável" que os sacerdotes cristãos (ibid.). Mas em seguida ele evoca os terríveis prejuízos trazidos pelo código de Manu aos indivíduos exteriores à casta, concluindo a esse respeito que "o conceito de 'sangue puro' é o oposto de um conceito inócuo" (GD/CI, Os "melhoradores" da humanidade 4, KSA 6.101). Certos comentadores estimaram, por isso, que Nietzsche rejeitava tanto a moral do amansamento quanto a moral da criação ${ }^{87}$.

Mas, para nós, essa leitura ignora o propósito maquiaveliano do texto. $\mathrm{O}$ último parágrafo, que constitui uma reelaboração do esboço de Tractatus politicus, oferece uma chave para a compreensão do conjunto da seção:

A moral da criação e a moral do amansamento são inteiramente dignas uma da outra nos meios de se imporem: podemos colocar como princípio máximo que, para fazer moral, é preciso ter a vontade

87 Cf., por exemplo, BROBJER, Th. The Absence of Political Ideals in Nietzsche's Writings. The Case of the Laws of Manu and the Associated Caste-Society. In: Nietzsche-Studien, n.27, p. 300-318, 1998.

196 | cadernos Nietzsche 32, 2013 
incondicional do oposto. [...] Expresso numa fórmula, pode-se dizer: todos os meios pelos quais, até hoje, quis-se tornar moral a humanidade foram fundamentalmente imorais (GD/CI, Os "melhoradores" da humanidade 5, KSA 6.102. Trad. modificada Paulo César de Souza).

Reencontra-se aqui o princípio fundamental de que todo "fundador de nova potência moral" deve ser um "imoralista da ação". Portanto, Nietzsche não vê justamente na imoralidade dos meios um motivo de condenação em si: para ele, não se trata de, por exemplo, censurar todos os moralistas que recorreram a mentiras piedosas em $O$ anticristo se lê, ao contrário, que uma mentira piedosa pode ser legitimada por sua finalidade ${ }^{88}$. Nietzsche recusa antes de tudo uma avaliação deontológica das fundamentações morais. Se toda moral está em contradição com seus modos de instauração, então, desse ponto de vista, todos os meios se equivalem e apenas uma avaliação consequencialista pode diferenciar duas morais particulares. Ora, $O$ anticristo nos diz claramente que a avaliação consequencialista dá a vantagem ao código de $\mathrm{Manu}^{89}$. Simplesmente se inverteria a tese de Nietzsche, portanto, ao se supor que ele rejeita a "moral da criação" por razões deontológicas.

Nossa conclusão é que Nietzsche concebe a eugenia como um conjunto de meios imorais a serviço de um fim superior. Ele tem consciência, como disse a Paneth em 1884, de que muitos se assustarão com a imoralidade de seu projeto. Mas ele responde como Maquiavel que, "se o fato acusa, o resultado escusa"

88 Cf. AC/AC 56, KSA 6.239: "Afinal, a questão é para que finalidade se mente. O fato de não haver finalidades 'santas' no cristianismo é a minha objeção aos seus meios" (trad. Paulo César de Souza).

89 Cf. AC/AC 57, KSA 6.241: "Surpreendemos a não-santidade dos meios cristãos in flagranti, se medimos a finalidade cristã pela finalidade do código de Manu - se colocamos sob luz forte esse enorme contraste de finalidades".

90 Cf. MACHIAVEL N. Discours sur la première décade de Tite-Live. In : Oeuvres complètes. Diversos tradutores, Paris: Gallimard (Pléiade), 1992, I, 9, p. 405. Maquiavel aplica essa frase ao assassinato de Remo por Rômulo, que tornou possível a fundação da República romana. 
como para nos convencer ex concessis a partir de nossos escrúpulos deontológicos, que todas as morais recorreram a meios assustadores para se impor. Não subscrevemos, no entanto, a essa argumentação: para além da condenação de princípio, ela parece criticável mesmo de um ponto de vista consequencialista. É a posição de Darwin que nos permitirá colocar isso em evidência.

Como mencionado na primeira parte, Darwin não contesta a existência de uma relação lógica entre a teoria da seleção natural e um projeto de seleção humana. Ele está disposto a conceder que a reprodução dos membros inferiores da sociedade terá "efeitos indubitavelmente ruins"91. Próximo ao fim de sua vida, ele estará mesmo tão preocupado com esse problema que ele exprimirá de modo privado pensamentos sombrios sobre o futuro da humanidade $^{92}$. Se ele não dá, todavia, o último passo em direção ao eugenismo, é porque julga o remédio mais perigoso do que o mal. Uma passagem importante de $A$ origem do homem o dá a entender:

O cirurgião pode endurecer-se enquanto pratica uma operação, pois ele sabe que age para o bem de seu paciente; mas se nós devêssemos intencionalmente negligenciar os fracos e desamparados, isso poderia ser apenas para um benefício contingente, com um mal presente esmagador ${ }^{93}$.

Estamos aqui diante de um raciocínio consequencialista, como indica a metáfora cirúrgica retomada ulteriormente por Féré e por Nietzsche. Darwin a rejeita antecipadamente, objetando que falta o elemento essencial: uma presunção suficiente do benefício futuro. Por um lado, é certo que seria preciso nos aviltarmos para excluir reprodutivamente os fracos. Mas, por outro, temos apenas hipóteses sobre as consequências dessa exclusão. A eugenia é assim

91 Cf. DARWIN, Ch. A origem do homem, p. 162, trad. modificada.

92 Cf. WALLACE, A. R. Human Selection. Op. cit., p. 325.

93 Cf. DARWIN, Ch. A origem do homem, p. 162, trad. modificada. 
uma caixa de Pandora que Darwin desaconselha fortemente a abrir. Pode-se estimar a esse respeito que a história das eugenias de Estado no século 20 lhe deu razão.

O problema axiológico assim levantado revela um limite fundamental do maquiavelismo. Admitamos que o príncipe maquiaveliano deva saber "entrar no mal" em nome de um fim superior. Para justificar sua ação, ele tem, todavia, a necessidade de uma forte presunção do benefício esperado. Porém, quanto mais se raciocina sobre uma longa duração e integrando numerosos fatores de probabilidade, menos se tem a possibilidade de se obter esse tipo de presunção. É assim no caso do eugenismo, em que se aspira a nada menos do que orientar a evolução de uma população durante várias gerações, a partir de um conhecimento parcial dos processos em jogo. $\mathrm{O}$ maquiavelismo não poderia entrar em consideração se os valores do resultado e da condição não são suscetíveis de uma comparação clara. Mas uma tal comparação parece justamente excluída em matéria de eugenismo, o que deveria nos incitar, ainda hoje, à mais alta prudência em face do desenvolvimento das tecnologias genéticas.

\section{Conclusão}

Tentamos mostrar neste artigo que Nietzsche foi efetivamente um pensador eugenista. Ele preconizou, de fato, um controle social da reprodução a serviço de sua axiologia. E ele o fez em numerosos textos publicados e póstumos, durante mais de uma década, referindo-se a partidários contemporâneos do eugenismo. As objeções filosóficas a essa leitura repousam geralmente em pressupostos definicionais contestáveis. Essas objeções parecem também inspiradas por uma preocupação apologética nascida após 1945. Mas, se elas provam a singularidade do eugenismo nietzschiano, elas não implicam que ele seja menos perigoso. Na verdade, a coerção e o maquiavelismo fazem do eugenismo nietzschiano um projeto mais radical do que o de Galton. 
Seria absurdo imputar unicamente a Nietzsche as eugenias institucionalizadas do século 20. Sem o apoio dos biólogos e dos psiquiatras, a eugenia não se teria traduzido em fatos e a voz do filósofo teria permanecido isolada. Tampouco Nietzsche podia prever que seu pensamento seria o objeto de um desvio antissemita. Contudo, os comentários que o isentam de qualquer responsabilidade não parecem convincentes. E conjecturamos que eles se tornaram supérfluos, agora que Nietzsche é amplamente reconhecido como o grande filósofo que ele é.

\begin{abstract}
The central thesis of this paper is that Nietzsche developed a eugenical project, which he justified through Machiavellian considerations. By eugenics is meant a political ideology aiming at controlling reproduction to serve a normative image of man. The first part (I) tries to establish the historical relevance of this definition. I then argue in favor of the existence of a Nietzschean eugenics (II). This interpretation rests on published and posthumous texts, as well as on Nietzsche's eugenical sources, among which I focus contemporary writers without omitting Plato. Finally, the third part (III) brings to light a certain Machiavellism of Nietzsche's eugenics, according to which repressing one's pity would be needed in order to achieve a higher goal.
\end{abstract}

Keywords: eugenics - biopolitics - Galton - Machiavellism

\title{
referências bibliográficas
}

DARWIN, C. A origem das espécies através da selecção natural ou a preservação das raças favorecidas na luta pela sobrevivência. Trad. Ana Alfonso. Leça da Palmeira: Planeta Vivo, 2009.

. On the various contrivances by which British and foreign orchids are fertilised

by insects, and on the good effects of intercrossing. London: John Murray, 1862.

. A origem do homem e a seleção sexual. Curitiba: Hemus, 2002.

DOMBOWSKY, D. Nietzsche's Machiavellian Politics. New York: Palgrave Macmillan, 2004.

FÉRÉ, C. Dégénérescence et criminalité. Essai physiologique. Paris: Félix Alcan, 1888.

200 | cadernos Nietzsche 32, 2013 
FRANK KRUMMEL, R. Joseph Paneth über seine Begegnung mit Nietzsche in der Zarathustra-Zeit. In: Nietzsche-Studien. Berlim/Nova York, n.17, p. 478-495, 1988.

FREZZATTI JUNIOR, W. Nietzsche contra Darwin. São Paulo: Discurso Editorial, 2001. GALTON, F. Hereditary Talent and Character. In: MacMillan's Magazine, London, vol. XII, p. 157-166 / p. 318-327, junho-agosto de 1865.

. Inquiries into Human Faculty and its Development. London: Macmillan, 1883.

GAYON, J. Nietzsche and Darwin. In: MAIENSCHEIN, J. / RUSE, M. (ed.) Biology and the Foundation of Ethics. Cambridge University Press, p. 154-197, 1999.

HAASE, M.-L. Friedrich Nietzsche liest Francis Galton. In: Nietzsche-Studien. Berlim/ Nova York, n.18, p. 633-658, 1989.

KAUfMAnN, W. Nietzsche. Philosopher, Psychologist, Antichrist. Princeton: Princeton University Press, 1974.

MACHIAVEL, N. Le Prince. Trad. C. Ferrari, Paris: Bibliothèque nationale, 1897.

MOORE, G. Nietzsche, Biology and Metaphor. Cambridge: Cambridge University Press, 2002.

NIETZSCHE, F. Sämtliche Werke. Kritische Studienausgabe in 15 Bänden. Berlim / New York: Walter de Gruyter, 1999.

NIETZSCHE, F. Sämtliche Briefe. Kritische Studienausgabe. Berlim / New York: Walter de Gruyter, 2003.

NIETZSCHE, F. L'Antéchrist. Trad. Éric Blondel, Paris: GF Flammarion, 1994.

PAUL, D., Controlling Human Heredity : 1865 to the Present. New York: Humanity Books, 1998.

PICHOT, A. L'Eugénisme ou les généticiens saisis par la philanthropie. Paris: Hatier, 1995.

PLATON. La République. Trad: Pierre Pachet, Paris: Gallimard, 1993.

RICHTER, C. Nietzsche et les théories biologiques contemporaines. Paris: Mercure de France, 1911.

SALANSKIS, E. La dimension eugéniste de la 'grande politique' de Nietzsche. In: CAMPIONI, G. / DENAT, C. / PIAZZESI, Ch. / WOTLING, P. (Org.) Nietzsche, penseur de la politique? Nietzsche, penseur du social?. Pisa: ETS 2013, p. 163-178.

SCHIRNHOFER, R. Vom Menschen Nietzsche. In: Zeitschrift für philosophische Forschung. Frankfurt, n.22, vol. 2, p. 250-260, 1968.

SCHOPENHAUER, A. Sämtliche Werke. Leipzig: Brockhaus, 3. Band, 1873.

TILLE, A. Von Darwin bis Nietzsche. Ein Buch Entwicklungsethik. Leipzig: C. G. Naumann, 1895.

Artigo recebido em 15/09/2012.

Artigo aceito para publicação em 20/10/2012. 